\title{
Pishenin I. \\ ANALYSIS OF MODERN \\ TENDENCIES OF MODERNIZATION \\ PROCESSES OF THE ENTERPRISES OF AIC OF UKRAINE
}

Об'єктом дослідження є підприємства агропромислового комплексу (АПК) України, які реалізують модернізаційні процеси.

Визначено, що відсутність єдиної концепції ефективної стратегї модернізації підприємств агропромислового комплексу виключає організаційний контекст. Транспортна інфраструктура забезпечує основні комунікаційні процеси та організаційні відносини, як найважливіші умови реалізацій модернізаційної стратегії підприємств агропромислового комплексу.

Теоретичною і методологічною базою дослідження є наукові праці дослідників зі стратегії модернізації, основним школам менеджменту і напрямків системного підходу до застосування ефективності ведення агропромислового бізнесу. При проведенні досліджень застосовувалися загальнонаукові та спеціальні методи досліджения: аналізу і синтезу, аналогій і порівняльного аналізу, метод декомпозиції. Такі методи маютьь істотні переваги в тому, що значно зменшується рівень ризику, а також рівень витрат на модернізаційні процеси.

Обгрунтовано особливості та основні закономірності модернізаційних процесів підприємств АПК України, які забезпечують сталий стратегічний розвиток економіки країни. Обгрунтовано положення, згідно якого, реалізація модернізаційних процесів є основною ланкою стратегічного розвитку економіки України та включає два основні блоки: формування транспортної інфраструктури для забезпечення багаторівневого інформаційного поля і реалізації структури на функціональному рівні. Це два самостійних етапи впровадження стратегії модернізаиії агропромислового комплексу України.

Виявлено основні проблеми та труднощі стратегії модернізащіі агропромислового комплексу, які обумовлюють стратегічний розрив - невідповідність практики реалізації стратегї модернізації існуючих стратегічним планам модернізації підприємств агропромислового комплексу.

Проблеми розділені на групи об'єктивного і суб'єктивного характеру. Це пов'язано з тим, що є присутнім високий рівень нестабільності впливу факторів зовнішнього середовища, а також суб'єктивні проблеми реалізації стратегії модернізації, які пов'язані з ефективністю використання трудового потенціалу на практиці.

Ключові слова: впровадження системи управління, підприємства агропромислового комплексу, транспортна інфраструктура, процеси модернізації.

\section{Introduction}

Strategic management of enterprises of the agro-industrial complex of Ukraine in different directions, as well as the wide implementation of organizational processes and technologies, are the main components of innovation processes. Among the growing economic and social importance of improving the entire economic system of agro-industrial complex, an important role is played by transporting agro-industrial products. The transport infrastructure of the agro-industrial complex, based on and integrating all factors of influence into a single compact production system, preserves industry segmentation, economic efficiency of transport services production and the domination of innovation activity.

Analyzing the peculiarities of the enterprises of the agro-industrial complex, it should be noted that they are related to the specifics of agrarian production, caused by the action of both natural and economic factors and are closely intertwined.

Natural factors include:

- territorial distribution of resources;

- use of land as the most important factor in production;
- seasonal agricultural production;

- interweaving of biological (associated with the use of plants and animals) and economic processes;

- specificity of processes of concentration of agrarian production.

The economic factors that determine the negative dynamics of agrarian production should include:

- low energy labor in most agribusiness enterprises; - price disparity, growing in the course of market transformations of domestic agriculture;

- an increase in the production of obsolete morally and physically agricultural machinery;

- a significant lag in agricultural production workers, which has been increasing over the years of market reforms, by the level of remuneration and provision of social infrastructure in comparison with employees of other industries based in cities.

The consequences of the mismatch of political governance and economic structure are the incompleteness of agrarian and land reform, the lack of preparedness of the agrarian sector for the global financial crisis, extinct villages and the migration of young people to cities and other countries. Such situation prompts the search for 
new ways of development in the agrarian environment. Full-scale modernization of agribusiness enterprises is the only opportunity to ensure long-term sustainable growth of agricultural production in accordance with the paradigm of sustainable development [1]. The analysis of modern tendencies of modernization processes is especially relevant given the threats and risks of anthropogenic, anthropogenic, natural, etc., and therefore requires further study and research.

\section{The object of research and its technological audit}

The object of research is the enterprises of the agroindustrial complex of Ukraine, which implement innovative technologies in the transport system of agro-industrial products. Noting the significance of scientific developments of scientists, one should note the insufficient disclosure of the scientific and methodological foundations of the modernization vector of improving the management system for the development of the transport infrastructure of the agro-industrial complex. Methodological approaches to determining the level of efficiency of the transport infrastructure are not formed.

To study modernization processes and identify their main trends, the formation and efficiency of the functioning of transport infrastructure was analyzed on the example of Ukrainian agroholding companies:

- Nibulon [2];

- Mriya [3];

- Astarta [4];

- Mironivskyi khliboprodukt [5].

These companies for the period of 2010-2017 provide a stable development of their activity and increase of sales volumes. The calculation of complex indicators of enterprise development was carried out in different directions of activity of these same enterprises.

As the basis of innovative activity of these companies in today's conditions is a change in market requirements, innovation leaders set a clear task: to anticipate the future needs of consumers and turn them into innovative transport technologies. At the same time, these enterprises for scientific research send significant sums, increase the number of engineering staff, apply organizational and economic mechanisms of cooperation to enhance innovation activities. The fact that the object of analysis is not only the quantitative indicators, it allows the results of the study to determine the various modernization strategies and innovative activity of enterprises.

\section{The aim and objectives of research}

The aim of research is identification of current trends in the modernization processes of the subjects of the agroindustrial complex in the sphere of introduction of innovative transport technologies.

To achieve this aim, the following tasks need to be addressed:

1. Justification of the prospects of the modernization process, based on the implementation of transport infrastructure.

2. Identification of the importance of the organizational component for the effectiveness of the process of modernization changes in the transport system.

\section{Research of existing solutions of the problem}

The comprehensive assessment of the current state of production and labor potential of the agrarian sector of the region gives grounds to assert that the production potential of the agrarian sector in general remains high. The analysis of development trends in recent years shows that the process of concentration of production in the agrarian sector continues [6], but its main focus will be the development of modernization processes. The problem of modernization processes is given enough attention by leading scientists in [7,8].

Scientific work [9] is devoted to the scientific and methodological principles of modernization in the agrarian sphere, but unresolved issues of the introduction of innovative technologies in the transport system of agroindustrial products are unresolved. The study of the issues of the strategy of institutional modernization of the agrarian sphere was carried out in [10]. However, this paper does not fully reveal the importance of the organizational component for modernization changes.

The author of the paper [11] substantiates the organizational and economic mechanism of modernization of the industrial-economic system of agrarian and industrial complex, but the questions remain to assess the effectiveness of the main organizational mechanisms of modernization changes.

An alternative solution to the problems of modernization of industrial enterprises is presented in [12], justified priorities, systems of planning of modernization changes, but the questions of transport provision of agro-industrial enterprises are not provided, taking into account the specifics of the agrarian sector.

The author of the paper [13] emphasizes the importance of obtaining a synergistic effect of agro-industrial integration. Although this statement can be considered by providing advanced transport infrastructure in the system of modernization of agricultural enterprises in the direction of integration processes.

The paper [14] examines the modernization of social and labor relations in today's economic conditions in Russia, which also solves similar problems, but social and labor relations have a mediated influence on modernization changes in the conditions of priority formation of the organizational structure of transportation of agricultural products.

According to the authors of the paper [15], the formation of the model of management of innovation development is the basic basis of the production system of enterprises, but this does not exclude the need to take into account the sectoral segmentation of transport services production.

The author of the paper [16] emphasizes the importance of modernization, although such statement can be considered from the side of the modernization processes of agribusiness enterprises in the area of transportation of agricultural products.

Thus, the results of the analysis allow to conclude that the uncertainty present in the modernization of transport processes is significantly reflected in the changes in the institutional framework of agribusiness enterprises, therefore the creation of a separate transport infrastructure is associated with a deep analysis of the issues of efficient use of resource potential. 


\section{Methods of research}

In the course of research, general scientific and special research methods were used:

a) analysis and synthesis - for:

- preliminary analysis of organizational technologies of management of agricultural enterprises as complex economic systems;

- determining the level of risks and assessing their impact on the result of enterprise management;

- study of features of information support of enterprises

in the context of transportation of products with the observance of the necessary technologies;

- analysis of the modern market and the influence

of factors of uncertainty on transportation processes;

b) analogies and comparative analysis - to determine the correlation of valuation characteristics of existing corporate transport management systems;

c) decomposition method has allowed to divide the problem in accordance with the new modernization tasks and apply model research on database design, detailed modelling of transport management processes in parallel with market research and marketing.

The use of these methods greatly contributed to the achievement of the research goal.

\section{Research results}

Implementation of the modernization strategy is a responsible task, more significant than the usual operational planning of cargo transportation.

If the high level of strategic positions of modernization processes is not ensured, then there are serious insurmountable barriers that significantly limit the stable development of the agro-industrial complex of Ukraine. Therefore, the task of this research in this field is identification and classification of the main problems of the modernization processes encountered by the agroholding enterprises in identifying ways and areas of action to find an effective system and model for implementing the modernization strategy of the agro-industrial complexes.

This research proposes a specific integrated structure that ensures efficient use of labor potential, high utilization of vehicles, organization of effective communication processes, and effective monitoring of the results of transportation of agricultural products. All these components exist in a systemic relationship and in certain relationships. Strategic analysis indicates the full interconnection between the factors of the external and internal environment of the organization, the possibilities for introducing innovative directions of development, the impact of threats from strategic planning in combination with the prospect of implementing a modernization strategy.

Thus, the basis of modernization processes is formed at the stage of setting the main goal of modernization. Today, in large differentiated agro companies it is necessary to ensure full synchronization of management decisions at all levels of management: corporate, functional and organizational. There is a need to create a system of balanced indicators and a mandatory redistribution of resources to provide interconnected modernization processes of different levels. It is quite obvious that the implementation of the modernization strategy is clearer in modern trends in the development of large agroholding enterprises.
The implementation of the modernization strategy should be structured and include two main stages: the formation of a transport infrastructure and an effective assessment of the results of its work. An assessment of results is a process of monitoring, analyzing and correcting possible deviations to determine the effectiveness of the use of resources.

A key feature of the modernization strategy for agribusiness enterprises is the emphasis on certain components of the process: those described in various scientific schools. The study of the main approaches to the features of modernization strategies gives the opportunity to significantly strengthen and deepen these provisions.

On the one hand, the modernization strategy is a rigid deterministic process. Possible deviations involve a mandatory correction of existing plans for technological processes, communication technologies and resource potential. However, it should be noted that the responsibility for the implementation of the modernization strategy should be taken into account in the hierarchy of the importance of managerial tasks and managerial decisions taken, as well as in determining strategic goals of enterprise development at different levels. An effective monitoring system provides for rapid response to possible deviations and appropriate actions. Responsibility for the measures included in the modernization strategy is determined irrespective of the possible implicit uncertainties of the situation [17].

If consider the formation of a modernization strategy at the design stage, then it is necessary to develop design models and to formulate pilot projects. It should take into account the recognition of mutual complementarity, which develops under the already formed strategy of modernization. Particular importance is attached to pilot projects that are implemented in parallel.

The main problems in implementing the modernization strategy are related to different methods and styles of making managerial decisions, with great resistance to changes in the implementation of modernization, conflicts of interest and the presence of certain contradictions. Systematic monitoring of factors of influence of external and internal environment allows to ensure operative adaptation of modernization development to changing conditions.

Problems related to managerial changes (organizational structure, corporate culture, management decision making systems) are identified with the processes of organizational transformation, therefore, many academic schools of modern strategic modernization provide consideration of labor potential as the main organizational component of all processes of interaction. A special place in this research is given to the questions of systematization of problems of the modernization strategy of enterprises of agrarian and industrial complex. This is due to the influence of the factors of the internal and external environment.

In this research, the main factors of influence are distributed by economic, social and environmental characteristics.

Economic factors should include: reducing the cost of transportation, improving the quality of services, reducing costs for product development, the emergence of new markets.

Social factors include: employment growth, diversification of the agro-industrial complex's economy, population welfare growth, and the development of rural areas.

To ecological - reduction of pollution, reduction of emissions and discharges, efficient use of natural resources.

A meaningful analysis of the influence of these factors shows that when improving the quality of transport 
services, the cost price of agricultural products is significantly reduced, which significantly contributes to increasing the competitiveness of agricultural products in the world markets. The creation of transport infrastructure involves the integration of transport sector enterprises and the increase of the efficiency of the use of transport resources and labor potential. Comprehensive development of labor potential takes place on the basis of stabilization of the agro-industrial complex, a significant improvement in the organizational structure of transport and the development of transport infrastructure.

\section{SWOT analysis of research results}

Strengths. The formation of transport infrastructure allows to realize the modernization tendencies of enterprises of agrarian and industrial complex due to implementation of two main functions which directly influence the possibility of modernization changes.

Firstly, transport infrastructure contributes to the formation of operational information within the enterprise on the necessary transportation of agricultural products, in order to determine the decisions taken to implement strategic plans. That is, the transport infrastructure provides the fastest, effective passage of management decisions.

Secondly, transport infrastructure provides for the achievement of effective coordination of vehicles, as well as the calculation of the economic efficiency of the trajectory of transportation of agricultural products.

The development of transport infrastructure at the regional and state levels provides for an increase in the investment attractiveness of the agro-industrial complex and the introduction of innovative transport technologies.

Weaknesses. In practice, transport infrastructure is determined by horizontal differentiation, a significant standardization of all technological processes, the specialization and regulation of transportation technology, the formation of effective communications in a single information space. Given the importance of these parameters, for successful modernization processes, it is necessary to provide detailed specifications for all technological processes of transportation of agroproducts.

Opportunities. In this research, the modeling of technological transport of agricultural products and the parallel work to study changes in the organization, as well as the assessment of the level of risk.

Threats. Obtained decomposition of the problem of modernization processes as a set of vertically structured problems allows to organize its step-by-step solution based on the integration of the system set of simple solutions, and each subsequent level of the system hierarchy is considered as the sum of the previous ones.

\section{Conclusions}

1. The analysis of the tendencies of the modernization processes of the enterprises of the agro-industrial complex makes it possible to conclude that the process of production concentration in the agrarian sector of the Ukrainian economy will continue, and its main direction will be the development of innovative technologies.

Creation of transport infrastructure meets the criteria for improving the efficiency of activities of agricultural producers.

2. The consolidation and reproduction of positive changes on its own basis involves working out a unified ideology of innovative development of agro-industrial complex, based on the implementation of an adequate organizational component for modern transport provision, taking into account the specifics of the functioning of the agrarian sector.

However, the share of the agrarian sector of the economy in the structure of the formation of gross domestic product of Ukraine needs to popularize knowledge about modern trends in the modernization of the agrarian sector among their leaders, employees.

\section{References}

1. Modernizatsiia suspilstva. URL: https://uk.wikipedia.org/wiki/ Модернізація

2. Ofitsiinyi sait Nybulona. URL: http://www.nibulon.com

3. Ofitsiinyi sait Mriia ahrokholdinh. URL: http://mriya.ua/

4. Ofitsiinyi sait Astarta ahropromkholdinh. URL: http://www. astartaholding.com

5. Ofitsiinyi sait «Myronivskyi khliboprodukt». URL: https:// www.mhp.com.ua

6. Zharun O. V. Investytsiina diialnist u silskohospodarskykh pidpryiemstvakh rehionu // Ekonomika APK. 2010. Issue 4. P. 83-87

7. Razumnova I. I. Novye tendentsii predprinimatel'skoy deyatel'nosti // USA-Kanada: Ekonomika, politika, kul'tura. 2005 Issue 9. P. 25-32.

8. Daft R. L. Management. Cengage Learning, 2013. Ed. 11. 752 p.

9. Heiets V. Liberalno-demokratychni zasady: kurs na modernizatsiiu Ukrainy // Ekonomika Ukrainy. 2010. Issue 3. P. 4-20.

10. Bochkov A. A. Strategiya institutsional'noy modernizatsii agrarnoy sfery: faktory, napravleniya, mekhanizmy: thesis of doctor of economic sciences. Rostov-na-Donu, 2009. 398 p.

11. Tselin D. S. Organizatsionno-ekonomicheskiy mekhanizm modernizatsii proizvodstvennokhozyaystvennoy sistemy regional'nogo APK: na primere Krasnodarskogo kraya: thesis of doctor of economic sciences. Rostov-na-Donu, 2008. 209 p.

12. Pidoymo L. P. Modernizatsiya promyshlennykh predpriyatiy: teoretiko-metodologicheskie osnovy, prioritety, sistema planirovaniya: thesis of doctor of economic sciences. Voronezh, 2005. $453 \mathrm{p}$.

13. Dankevych Ye. M. Synerhetychnyi efekt ahropromyslovoi intehratsii // Innovatsiina ekonomika. 2012. Issue 7 (33). P. 190-193

14. Dudko V. N. Modernizatsiya sotsial'no-trudovykh otnosheniy v Rossii v sovremennykh ekonomicheskikh usloviyakh: thesis of Doctor of Economic Sciences. Saratov, 2009. 378 p.

15. Titov A. B., Vasil'tsov V. S. Formirovanie modeli upravleniya innovatsionnym razvitiem khozyaystvennoy sistemy // Nauchnotekhnicheskie vedomosti Sankt-Peterburgskogo gosudarstvennogo politekhnicheskogo universiteta. 2013. Issue 180. P. 49-54.

16. Smirnov O. Modernizatsiya bez innovatsiy - eto tupik. 2010 URL: http://www.ng.ru/politics/2010-03-24/1 modernize.html

17. Bowersox D., Closs D., Cooper M. B. Supply Chain Logistics Management. McGraw-Hill Education, 2012. Ed. 4. 496 p.

Pishenin Igor, PhD, Department of Management, Chernihiv National University of Technology, Ukraine,e-mail: pishenina@ukr.net ORCID: http://orcid.org/0000-0002-4544-5076 